\title{
LAVA CAKE FOR THE APOCALYPSE
}

\section{A taste of history.}

\section{BY WENDY NIKEL}

\section{2 tablespoons wheat flour}

Yes, Admiral, I know we have developed superior, genetically enriched starches on the New Worlds, but when I found this crumbling recipe card in the archives and realized it was written in your great-great-greatgrandmother's hand, I thought it would be fitting to bake it as accurate to Earth-era as possible. As I was already scheduled for the reconnaissance mission back to humanity's birthplace, I thought I'd return with a little something extra to celebrate its impending destruction.

The flour wasn't too difficult to acquire, utilizing archived maps to pinpoint the area that used to be called the Wheat Belt. I don't know what it's called now; my search of the past century's communications between Earth and the New Worlds didn't provide any clues. The transmissions were infrequent and mainly consisted of lists of resources we required from Earth to enable our exploration and extend humanity's reach.

After our long flight across the stars and down through Earth's cloud-swept skies, Jabber and I set the Drifter down beside a rusted-out corpse of a tractor. I stared in awe at the amber waves rising up around us, still swaying in the breeze after all this time. Their seeds' texture on my tongue was peculiar, and I suddenly understood why we call things 'grainy'.

"Hurry up," Jabber called anxiously from the Drifter. "We've got some Earthers approaching from the north!"

Quickly, I stripped a handful of stalks and hurried back to the ship.

\section{3 ounces chocolate}

We headed south to find cacao trees on the plateau where my ancestors once lived.

After the Earthers' mutinous transmission - the one that started all this talk of restitution and repercussions and nuclear war - I spent some time alone in the archives, sifting through our collective history, trying without avail to uncover their motives.

I wondered: if I'd been planet-bound instead of sky-born, would I, too, be so backward-thinking and ignorant as to refuse our supply requests? Would I be so short-sighted as to deprive humanity of what we needed for life beyond Earth's orbit? I didn't know.

Maybe that's why I took your grandmother's notecard.

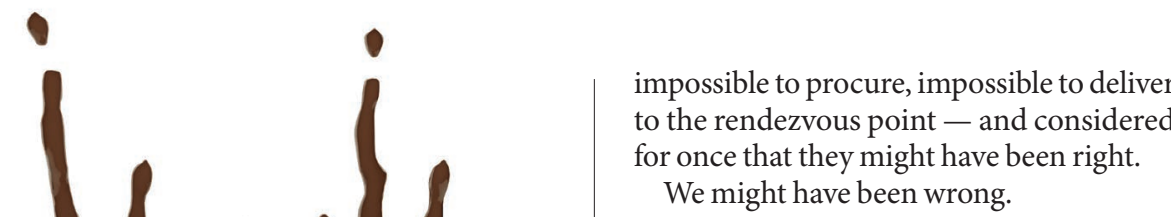

1 egg

As Jabber flew, I scanned the ground, searching now for what wasn't there. In a thick clump of trees loomed the shadow of a forgotten factory, its smokestacks twined with lush vines. Beneath the river's surface was the outline of a bus, draped with olive-green algae. A field of stones slowly resolved into the shape of a town, abandoned streets delineated with darker grey.

On and on, we flew past the shadows of our civilization.

We landed near a farm with a chicken coop beside it, amid a ramshackle cluster of houses. I ducked inside the tiny enclosure to pocket a single, warm egg.

"Who are you?" A woman wearing an apron suddenly blocked my path, leading a bored, brown cow. Jabber would kill me if he knew I'd let them surprise me.

I raised my hands and said the only thing that came to mind: "Please, ma'am. Do you have any butter?”

\section{1 teaspoon butter}

Jabber didn't bother asking where I'd got the hand-painted bowl with the generous dollop of butter cradled inside. I think he was just glad to leave. But all the while, as the Drifter sped across the Galaxy and Earth grew smaller in the window, I couldn't stop thinking of the empty cities, the apron-clad milkmaid, and the child with the void in his eyes.

The cake fell in the middle and the edges are too crisp, but I want you to have it regardless. I want you to taste for yourself your greatgreat-great-grandmother's world - sweet and bitter and complex.

Taste a world worth saving.

Wendy Nikel is a speculative-fiction author with a degree in elementary education, a fondness for road trips and a terrible habit of forgetting where she's left her cup of tea. Her short fiction has been published by Fantastic Stories of the Imagination, Daily Science Fiction, Nature and elsewhere. Her time-travel novella, The Continuum, was published by World Weaver Press in January 2018. For more info, visit wendynikel.com. 